\title{
Occurrence of helically coiled microfossil Obruchevella in the Owk Shale of the Kurnool Group and its significance
}

\author{
Mukund Sharma* and Yogmaya Shukla \\ Birbal Sahni Institute of Palaeobotany, 53 University Road, Lucknow 226 007, Uttar Pradesh, India. \\ *Corresponding author.e-mail: mukundsharma@bsip.res.inｙogmayashukla@gmail.com
}

The present study reports occurrence of helically coiled microfossil Obruchevella Reitlinger from the Owk Shale of the Kurnool Group from the peninsular India. The age of the Kurnool Group is poorly constrained due to the absence of direct radiometric dating and meager palaeobiological data. Occurrence of Obruchevella is considered as a typical Vendian marker genus recorded mostly from close to the Precambrian-Cambrian boundary successions. Hence, the present assemblage is important to ascertain the age of the basin. In the Owk Shale, four species of Obruchevella, viz., O. delicata, O. parva, O. minor and $O$. valdaica are recorded as organic walled microfossils. Among them O. valdaica is the largest in terms of size parameters. On the global scale, the recovered species occur in the Late Neoproterozoic to Early Cambrian sediments. Therefore, the occurrence of microfossil Obruchevella in the Owk Shale and known burrow structures in the Narji Limestone suggest Ediacaran age close to the Cambrian for the Kurnool Basin and challenges the recently assigned Mesoproterozoic age of the basin.

\section{Introduction}

Carbonaceous microfossils are the important element of the Precambrian biosphere. Among them, the helically coiled microfossils though distinct, are problematic. These are broadly divided into $\mathrm{Ob}$ ruchevella, Volyniella (subsequently merged with Obruchevella), Boruokia, Grypania and Spirillopsis. They occur in shales, chert and carbonate rocks and are recorded from Australia, Alaska, Canada, China, Greenland, India, Mongolia, Russia and Saudi Arabia (see Peel 1988; Mankiewicz 1992; Burzin 1995). Obruchevella Reitlinger is the commonly recorded helically coiled microfossil that range in age from Riphean to Devonion and most of them are reported from close to the PrecambrianCambrian boundary successions. In Indian sedimentary successions, in extra peninsular region, these are reported from Tal Formation (Ahluwalia 2002), Infra-Krol Formation (Tiwari and Knoll
1994), Krol Formation (Kumar and Rai 1992), Buxa Formation (Shukla et al 2006; Tewari 2007; Tiwari and Pant 2009) and in the peninsular region in Bhander Group (Prasad et al 2005; Prasad 2007) and Salkhan Limestone (Rai and Singh 2004). Helically coiled microfossils of Himalaya occur in the Precambrian-Cambrian successions whereas those of the peninsular region have been suggested to be of Palaeo-Mesoproterozoic age. In the present paper, we are reporting the first occurrence of the helically coiled microfossil from the Owk Shale of the Kurnool Group in the peninsular India. All the previously reported forms were described in terms of the morphology of the helix diameter and filament diameter but data on pitch, which conveys about the tightness of the coiling, were not provided. In the present paper, the Kurnool helically coiled microfossils are taxonomically described; their preservation, affinity and age connotation have also been discussed.

Keywords. Owk Shale; Kurnool; Obruchevella; hellically coiled microfossils; Neoproterozoic; India. 
The age of the Owk Shale as well as the entire Kurnool Group is poorly constrained due to the absence of direct radiometric dating of any of the lithounits and the palaeobiological data of the basin are also meager. Indirect evidence suggests the Mesoproterozoic age of the basin (Dongre et al 2008) which is contradictory to what is inferred from the available palaeobiological data. In this case, the record of genus Obruchevella is important to ascertain the age of the basin as it is considered as typical Vendian. It is known from cherts, shale, limestone, dolomite and phosphorite. In the Owk Shale, four species of Obruchevella are recorded, viz., O. delicata, O. parva, O. minor and O. valdaica. All four species have known occurrences from the Late Neoproterozoic to the Early Cambrian. Although a few (older Neoproterozoic) specimens of Obruchevella are known, Vendian-Lower Cambrian acme of this genus is a real phenomenon (Knoll 1996). The Owk Shale overlies the Narji Limesone from where bioturbation structures in the form of worm burrows were reported (Vijayam 1967; Arya and Rao 1979). The presence of worm burrows indicate the animal activity towards the end of uppermost Proterozoic or even the Lower Cambrian age of the strata. The occurrence of helically coiled microfossils Obruchevella from the Owk Shale together with the burrow structures in the Narji Limestone suggest an Ediacaran age close to the Cambrian for the Kurnool Basin. The present study, thus, challenges the recently assigned Mesoproterozoic age of the basin.

\section{General geology and age}

A long period of quiescence followed the Cuddapah Supergroup sedimentation in the south by the tectonic activities between 1100 and 900 Ma (Valdiya 2010). Fresh sedimentation cycle was marked with angular unconformity. This sedimentation resulted in two cycles of quartzite-limestone-shale deposition and is known as the Kurnool Group. The sediments of the Kurnool Group were invariably deposited over the different units of the Cuddapah Supergroup (figure 1a). The lithostratigraphic succession of the Kurnool Group is given in table 1. The Kurnool Group sediments are exposed in Kundair Valley in the west and the Palnad area in the northeast. In the Kundair Valley, the Kurnool Group sediments unconformably overlies the basement gneisses and different members of the underlying Papaghani and Chitravati Groups.

Impersistent horizon of $10-50 \mathrm{~m}$ thick conglomerate and sandstone form the base of the Banganpalle Formation. It is a source of detrital diamonds. Overlying this unit is the Narji Limestone which is extensively developed in the region. It is massiveto-flaggy in nature. The buff, white and purple shales constitute the Owk Shale that overlies the Narji Limestone. The Quartzite and the conglomerates of the Banganpalle Formation are considered to have deposited in alluvial setting (Lakshminarayana et al 1999) whereas, the Narji Limestone represents the basinal limestone with almost no terrestrial input. The onset of the second cycle is marked by the occasional conglomerate of the Paniam Quartzite. The Koilkuntla Limestone is siliceous and flaggy in nature with pockets of good quality limestone. It gradually passes into purple coloured Nandyal Shale. The cyclic nature, sedimentological structures and lithologic association indicate overall shallow marine depositional environment that range between beach, littoral, tidal-flat and lagoonal environment (Lakshminarayana et al 1999).

Age: The Banganpalle Quartzite of the Kurnool Group is diamond bearing and source of the diamonds are considered to be Vajrakarur Kimberlite which has been dated as $1140 \mathrm{Ma}$ (Crawford and Compston 1973). If it is correct then the Kurnool sedimentation is younger than 1140 Ma. Raman and Murthy (1997) proposed the maximum age of $980 \mathrm{Ma}(\mathrm{Rb} / \mathrm{Sr})$ and minimum age of $500 \mathrm{Ma}$ (K/Ar) for the shales of the Kurnool Group. Recently, Dongre et al (2008) studied minerology, major and trace element geochemistry, stable isotope studies of a limestone xenolith found intruded in the Siddanpalli Kimberlite and suggested Late Mesoproterozoic age (older than $1090 \mathrm{Ma}$ ) to the Kurnool basin. Limestone xenolith has been considered to be the part of the sedimentary rocks which were available in the vicinity of Kimberlite emplacement. The Bhima and the Kurnool basins were the closest sedimentary rocks inferred to be inter-connected at the time of kimberlite intrusion.

Helically coiled fossils described in this paper have been recovered from the Owk Shale exposed on the eastern part of the hillock $\Delta 1445$ situated in the village Ankireddipalle $\left(15^{\circ} 07^{\prime}: 78^{\circ} 03^{\prime}\right)$ and Petnikota $\left(15^{\circ} 5^{\prime}: 78^{\circ} 4^{\prime}\right)$ areas of the Kurnool district of Andhra Pradesh. Exposed thickness of the Owk Shale on these spots are about $15 \mathrm{~m}$.

\section{Previous studies}

King (1872) did not reported the presence of any biotic signatures in the Kurnool sediments, however, dark spotted circular structures were mentioned by him as the cycloid scales of fish. Rajurkar (1963) restudied these structures and compared them with Fermoria, now considered, as junior synonym of Chuaria. Sharma and Shukla (1999) made a detailed account of carbonaceous remains from the Owk Shale. The carbonaceous remains consisted of compression and impressions belonging 


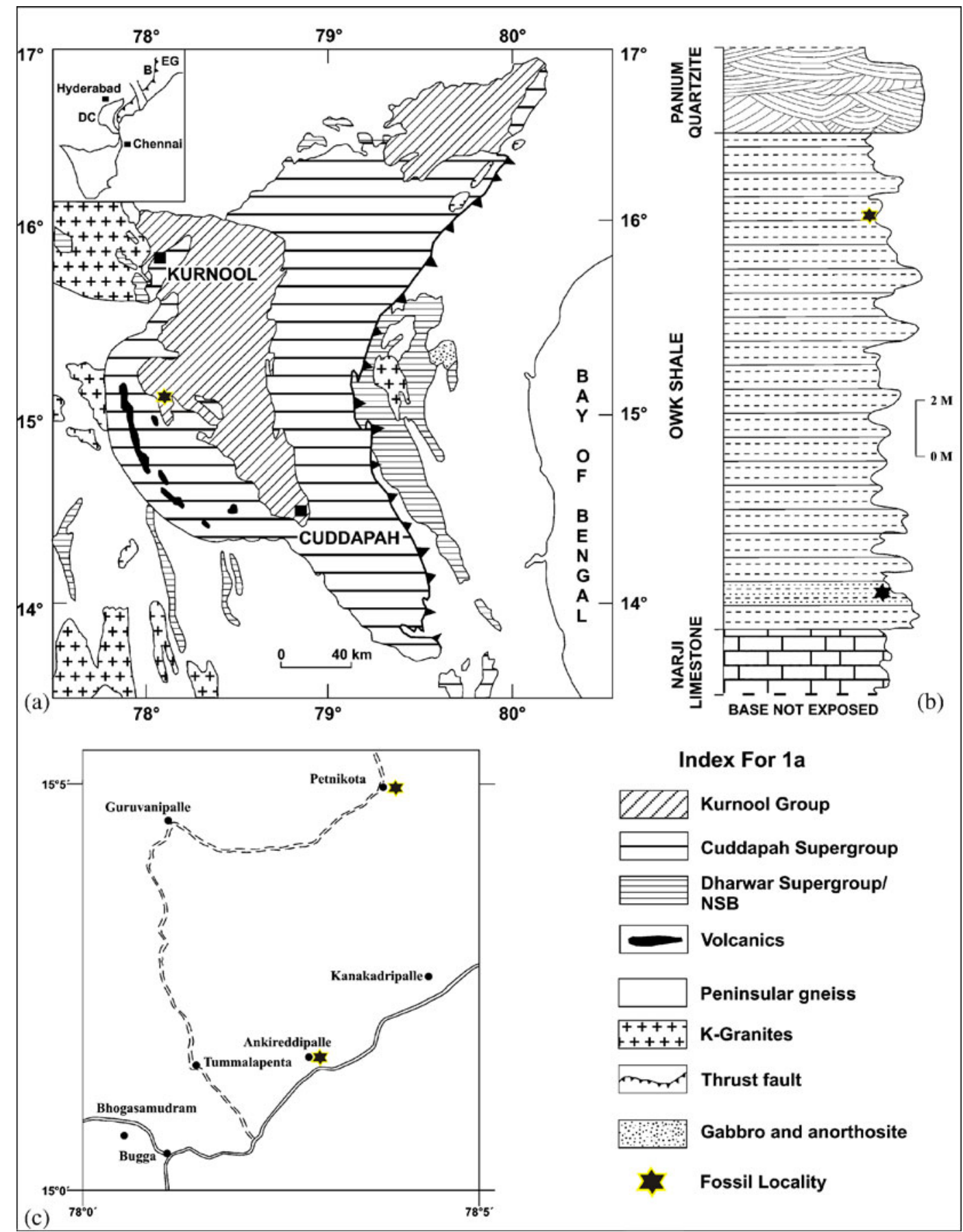

Figure 1. (a) Generalized geological map of the Kurnool basin (after Misra 2011). (b) Lithostratigraphic succession exposed at Ankireddipalle village, Kurnool district, Andhra Pradesh showing Narji Limestone, Owk Shale, and Panium Quartzite. Asterisk indicate the level of the occurrence of carbonaceous fossils. (c) Locality map of the fossils yielding areas in Ankireddipalle village, Kurnool district of Andhra Pradesh.

to Chuarid, Tawuid, Ellypsophysid, Moranid and Beltinid groups. They correlated the Owk Shale with the Bhander Group of the Vindyan Supergroup and the Halkal Formation of Bhima basin of the peninsular region. Salujha et al (1972) reported that microplankton assemblage consisted of the genera Leiosphaeridia, Lophosphaeridium, Granomarginata, Archaeofavosina, Protoleiosphaeridium,
Dictyotidium, Leiovalia, Micrhystridium and Priscogalea. These genera are long ranging in age and were compared to the Bhima assemblage. Bioturbation structures in form of worm burrows were reported by Vijayam (1967) from the Narji Limestone. Occurrence of worm burrows were viewed as evidence of existence of invertebrates and thus the uppermost Proterozoic or Lower Cambrian 
Table 1. Lithostratigraphy of the Kurnool Group of the Cuddapah basin (after Nagaraja Rao et al 1987).

\begin{tabular}{|c|c|c|}
\hline \multirow{6}{*}{ Kurnool Group } & Nandyal Shale & $(50-100 \mathrm{~m})$ \\
\hline & Koilkuntla Limestone & $(15-50 \mathrm{~m})$ \\
\hline & Paniam Quartzite & $(10-35 \mathrm{~m})$ \\
\hline & Owk Shale & $(10-15 \mathrm{~m})$ \\
\hline & Narji Limestone & $(100-200 \mathrm{~m})$ \\
\hline & Banganpalle Formation & $(10-50 \mathrm{~m})$ \\
\hline----- & $\begin{array}{r}\text { Cudd: Srisailam Q }\end{array}$ & $-\cdots-\cdots$ \\
\hline
\end{tabular}

age was assigned to this formation. Subsequently, worm burrows belonging to Skolithos and Glossifungites assemblage were reported by Arya and Rao (1979) and the Ediacaran age was assigned to the Narji Limestone. Sharma (2008) reported forms like Twitiya discs and Cyclomedusa sp. from Panium Quartzite formation that are typical Ediacaran in age.

\section{Material and methods}

Specimen described in the present paper are recovered from the Owk Shale of the Kurnool Group exposed in south India. Shale samples were macerated with traditional method. Organic residues were mounted on the slides. Specimens were studied under transmitted light on Nikon Eclipse 80i Microscope in BSIP. England Finder co-ordinates are given in parenthesis for each figure. The slides are deposited in the repository of the Birbal Sahni Institute of Palaeobotany Museum bearing number BSIP-14394-BSIP-14407 with statement no. 1301.

\section{Systematic palaeontology}

Genus: Obruchevella Reitlinger, 1948

Obruchevella Reitlinger 1948, p. 78, 1959, p. 21; Luchinina, 1975, p. 29; Kolosov, 1977, p. 73; Yakschin and Luchinina, 1981, p. 29; Kolosov, 1984, pp. 57-58; Song, 1984, p. 181, 183; Yankauskas, 1989, pp. 112-113; Burzin, 1995, pp. 7-9; Nagovitsin, 2000, p. 14.

Volyniella Schepeleva and Aseeva in Aseeva, 1974, p. 95; Pashkevichene, 1980, p. 48; Kolosov, 1984, p. 53.

Type species: Obruchevella delicata Reitlinger, 1948.

Diagnosis: Empty tubes, sometimes with rare septa coiled into regular cylindrical spiral, sometimes taper or expanding towards ends. In these spirals tubes, walls usually are tightly joined to one another or in rare cases, they can be loose.

Remarks: Microfossil genus Obruchevella has been recorded mainly as permineralized remains in cherts or silicified phosphorites as well as in the dolomites and as macerates residue from shales. Spirals of Obruchevella originally were described as foraminifera from the Vendian (Ediacaran) Tinna and Lower Cambrian Sinna Formations of Siberia (Reitlinger 1948, 1959). Later, these fossils were reinterpreted as remains of oscillatoriacean cyanobacteria similar to modern cyanobacterium genus Spirulina (Luchinina 1975; Yakschin and Luchinina 1981; Yankauskas 1989). The spiral forms from shales were described independently as genus Volyniella (Aseeva 1974) but subsequently merged with genus Obruchevella (Yankauskas 1989; Sergeev et al 2012). Besides above-mentioned taxa, many more genera of spiral micro-organisms were described during a half-century study of Proterozoic microfossils, e.g., Avictuspirulina, Glomovertella, Glomerula, Spirellus, Spirillopsis, Boruokia, Jiangispirellus and others. However, almost all these taxa can be considered as the degradational or ecological variants of genus Obruchevella (table 2).

Contents: O. blandita, O. condensata, O. crassa, O. cylindrica, O. delicata, O. ditissima, O. exilis, O. gigantea, O. inviolata, O. magna, O. meishucunensis, O. minor, O. minuta?, O. parva, O. parvissima, O. pusilla?, O. sibirica, O. tungusica, O. turukhanica, O. uralense and $O$. valdaica.

Age: Neoproterozoic.

Obruchevella delicata Reitlinger, 1948

Figure 2(a-m)

Obruchevella delicata Reitlinger, 1948, p. 78, 80, pl. I, figures 1, 2; Reitlinger, 1959, p. 21, pl. VII, figures 1-3; Luchinina, 1975, p. 29, pl. XXVII, figures 3-5; Yakschin and Luchinina, 1981, pp. 29-30, pl. IX, figures 1-5; Pyatiletov et al, 1981, figure 1.7; Song, 1984, figure 3.13; Sergeev and Ogurtsova, 1989, 
苟

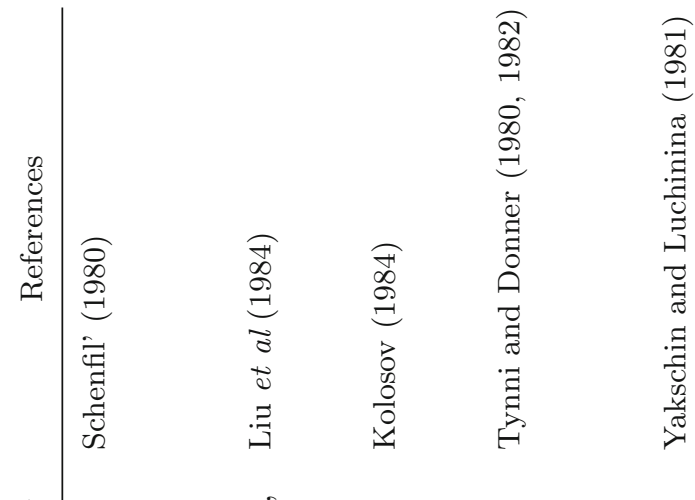

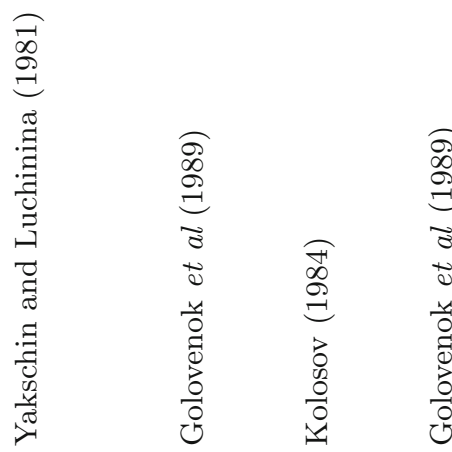

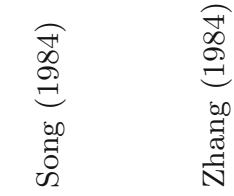

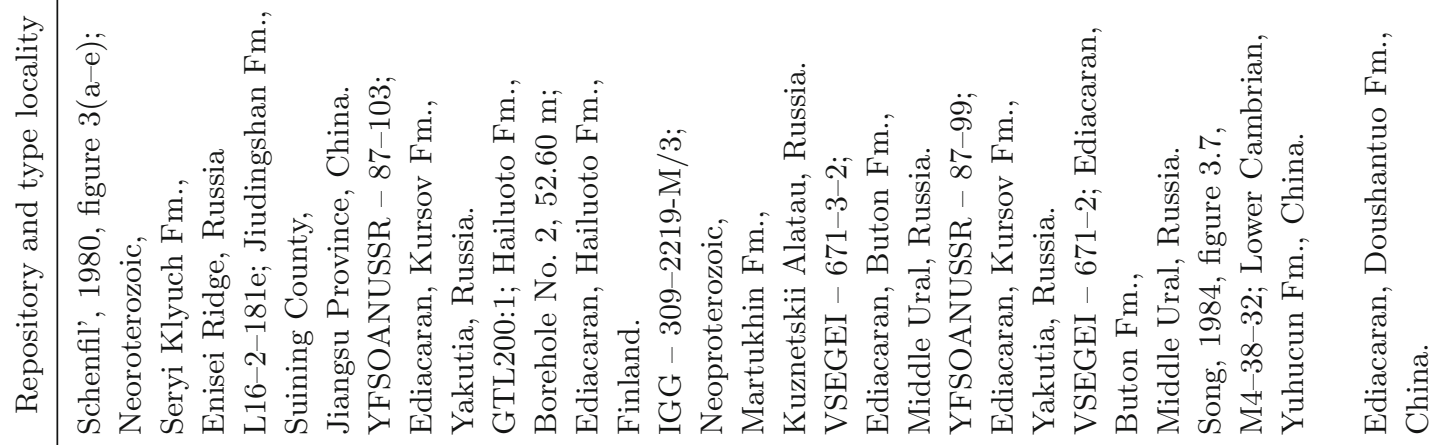

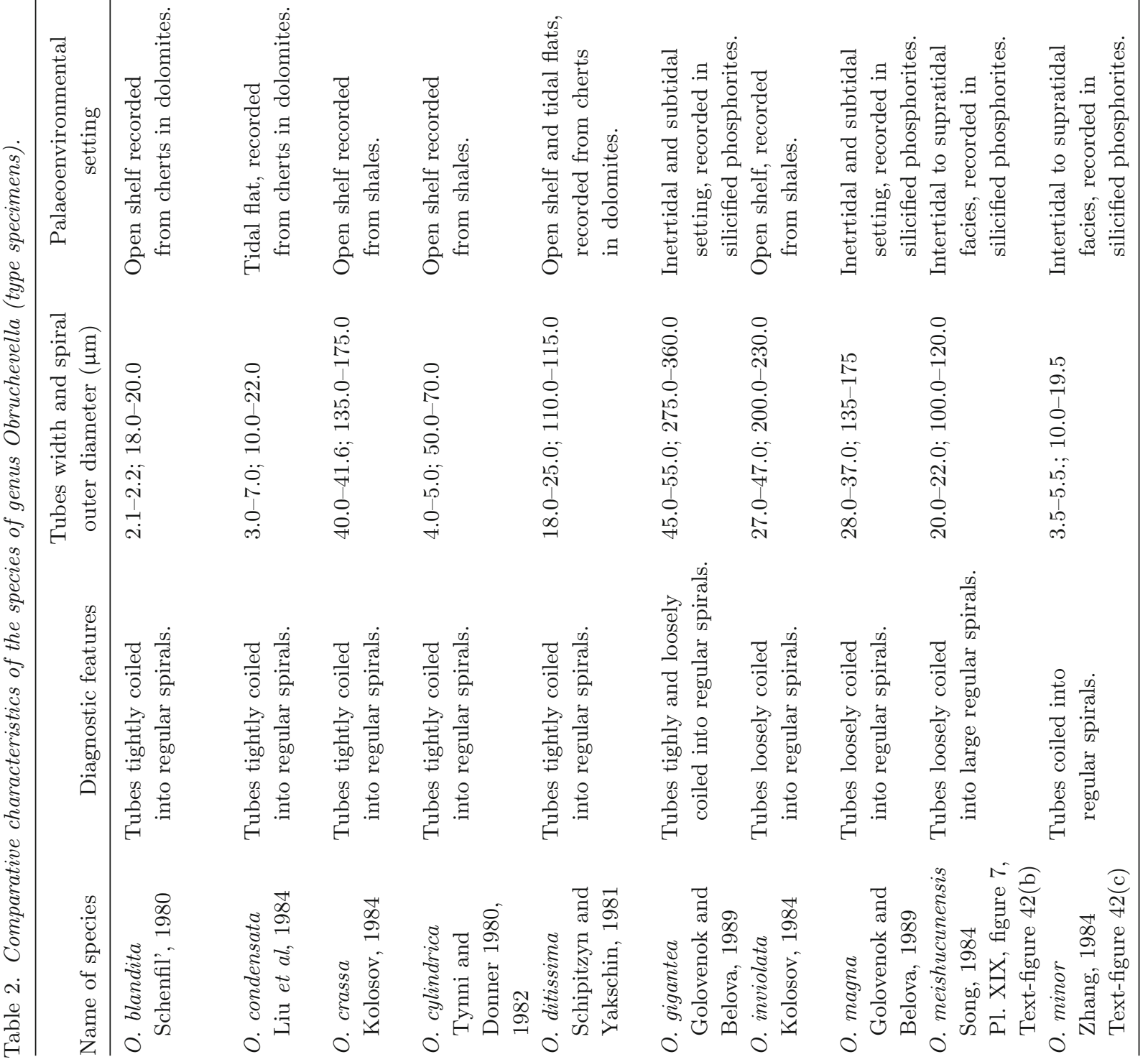




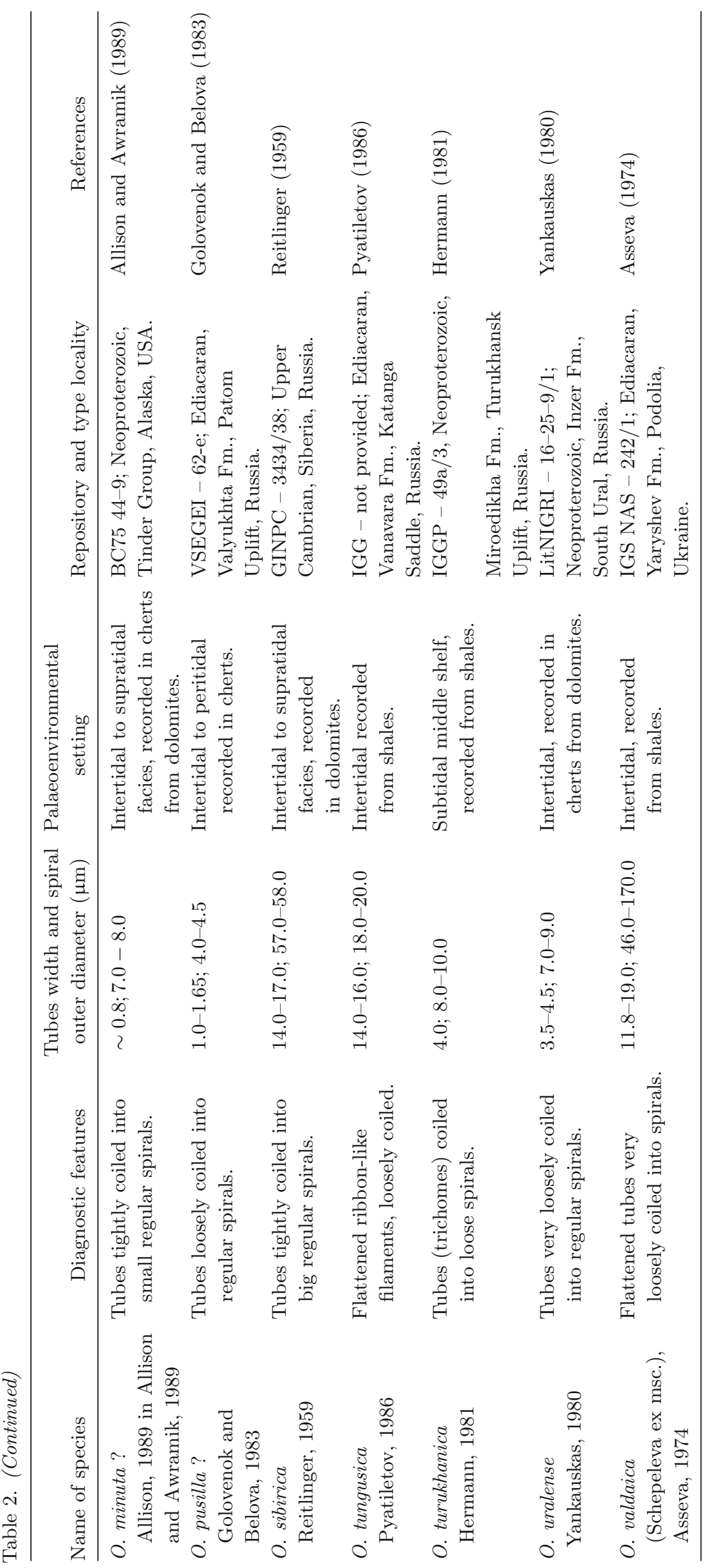


(a)

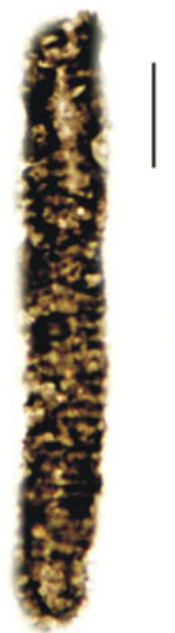

(a)

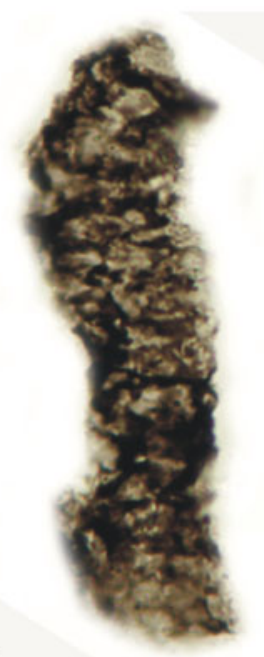

(f)

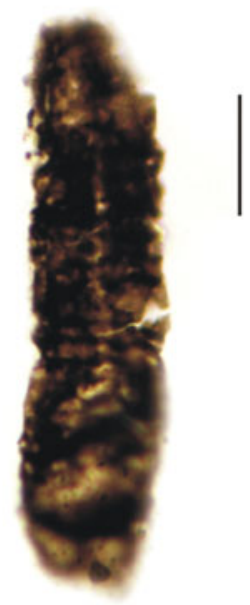

(j)

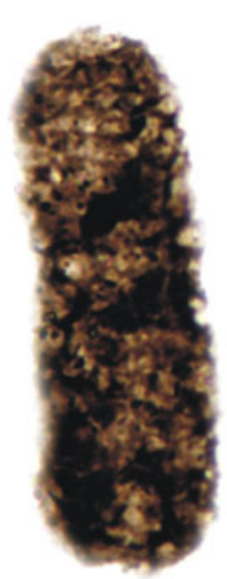

(b)

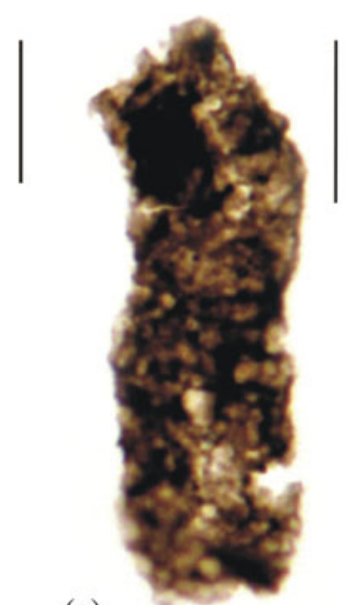

(c)

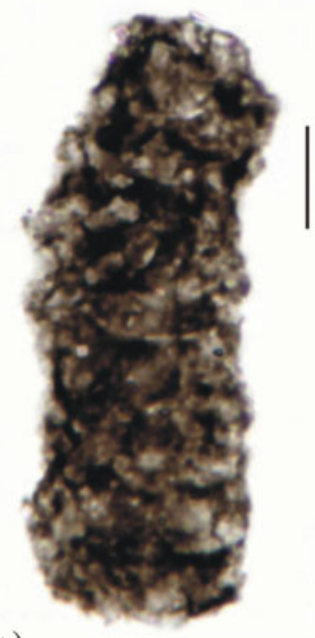

(g)

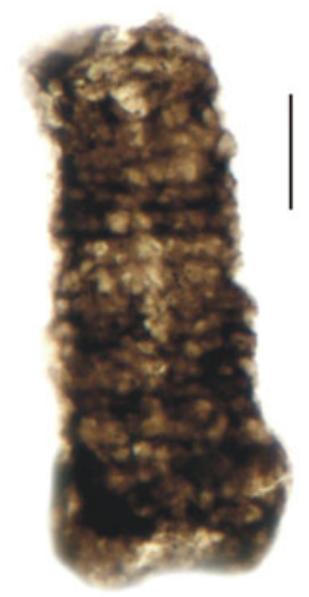

(h) (d)
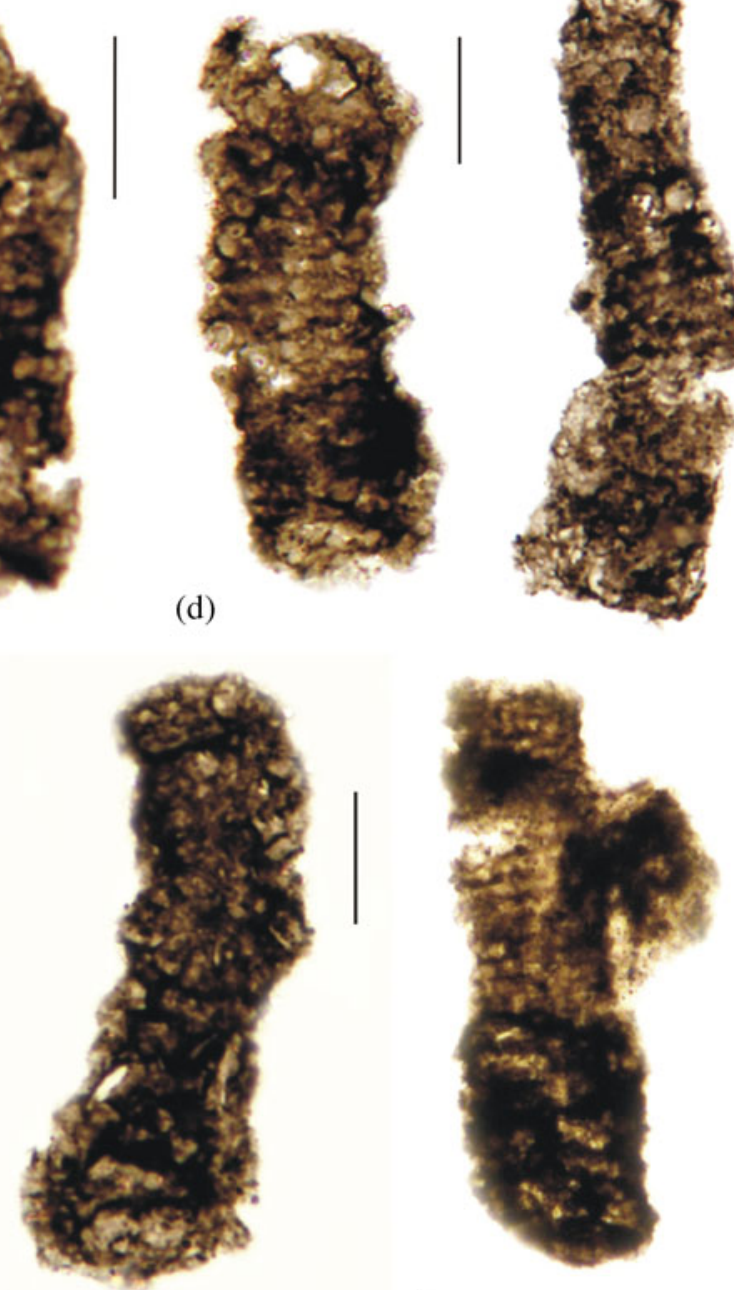

(i)
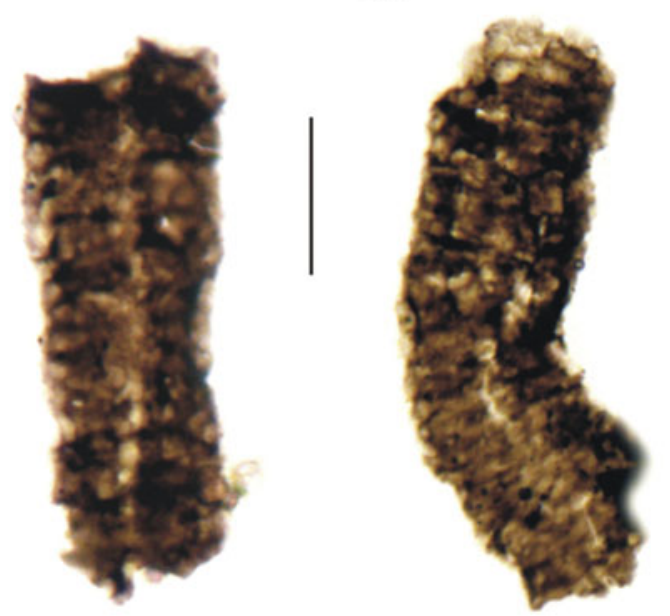

(e)

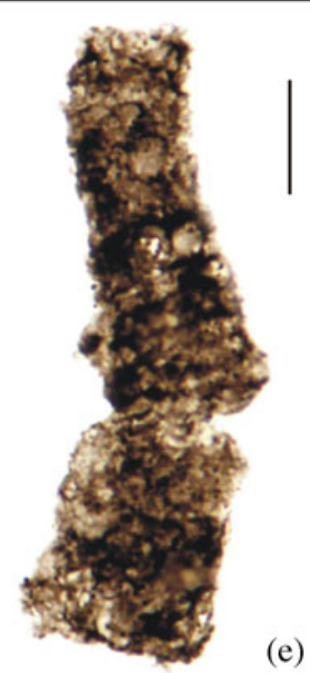

(1)

(m)

Figure 2. Helically coiled microfossils recorded from the Owk Shale of the Kurnool Group. In this and all following figures, slide catalogue number for the Birbal Sahni Institute of Palaeobotany Museum (BSIP) and England Finder coordinates for each illustrated fossil is given in brackets. Note the tightly coiled structure of each specimen. Except $\mathbf{b}$ and $\mathbf{j}$, all are incomplete specimen. (a-m) Obruchevella delicata Reitlinger (a) (BSIP-14404; U41/2), (b) (BSIP-14403; R54/3), (c) (BSIP-14394; G41), (d) (BSIP-14407; R33/2), (e) (BSIP-14407; W45/3), (f) (BSIP-14400; D44), (g) (BSIP-14401; O69), (h) (BSIP-14405; N66/4), (i) (BSIP-14399; V44/4), (j) (BSIP-14394; O68), (k) (BSIP-14397; Q56/2), (l) (BSIP-14398; $\mathrm{K} 53 / 2),(\mathbf{m})(\mathrm{BSIP}-14394 ; \mathbf{F} 66)$. Scale bars $=50 \mu \mathrm{m}$ for $\mathbf{i} ; 20 \mu \mathrm{m}$ for $\mathbf{a}-\mathbf{f}, \mathbf{h}, \mathbf{j}-\mathbf{m} ; 10 \mu \mathrm{m}$ for $\mathbf{g}$. 


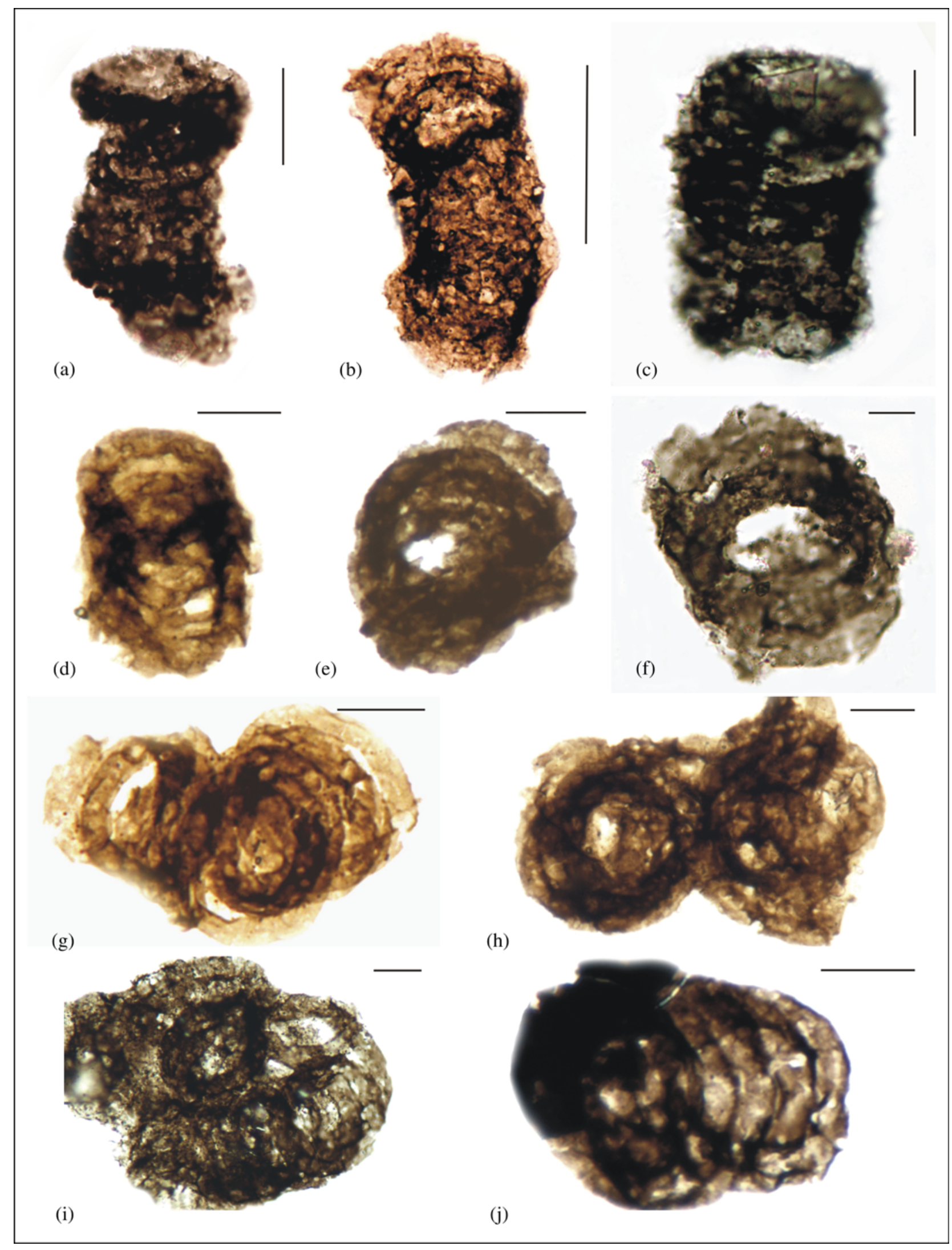

Figure 3. Helically coiled microfossils recorded from the Owk Shale of the Kurnool Group. Note the loosely coiled helical structure of each specimen. (a-j) Obruchevella parva Reitlinger, 1959 (a) (BSIP-14400; J47), (b) (BSIP-14405; K62), (c) (BSIP-14400; R57), (d) (BSIP-14397; R45/4), (e) (BSIP-14399; V31), (f) (BSIP-14401; Q42/2), (g) (BSIP-14396; K50), (h) (BSIP-14397; P41), (i) (BSIP-14395; Q36), (j) (BSIP-14396; P55). Scale bars for $\mathbf{a}=50 \mu \mathrm{m} ; \mathbf{b}, \mathbf{d}, \mathbf{e}, \mathbf{g}-\mathbf{j}=20 \mu \mathrm{m}$ and c, $\mathbf{f}=10 \mu \mathrm{m}$. 


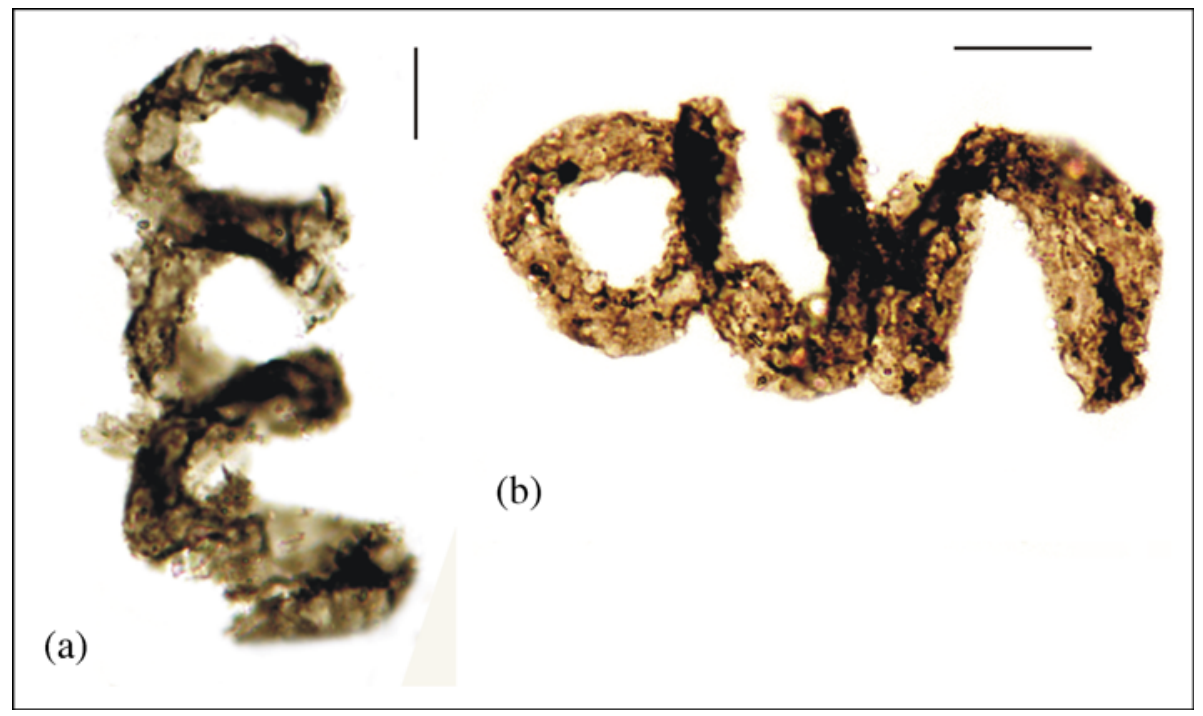

Figure 4. Helically coiled microfossils recorded from the Owk Shale of Kurnool Group. Note very loosely coiled helical structure of the specimens. (a-b) Obruchevella minor Zhang (a) (BSIP-14401; K44/3), (b) (BSIP-14405; X33/4).

pl. I, figure 4; Golovenok and Belova, 1989, pp. 193-194, figures 1e-13; Sergeev, 1992a, pp. 89-90, pl. XXV, figures 7a, 7б; Mankiewicz, 1992, figures 6.1-6.5, 8.1-8.7; Prasad et al, 2005, pl. 10, figures 7, 11, pl. 11, figure 11; Prasad, 2007, pl. 1, figures $4,7,8,14,18$.
Stratum typicum: Lower Cambrian, Sinna Formation, Patom Uplift, Russia.

Description: Empty tubes, sometimes with rare septa coiled into regular cylindrical spiral do not

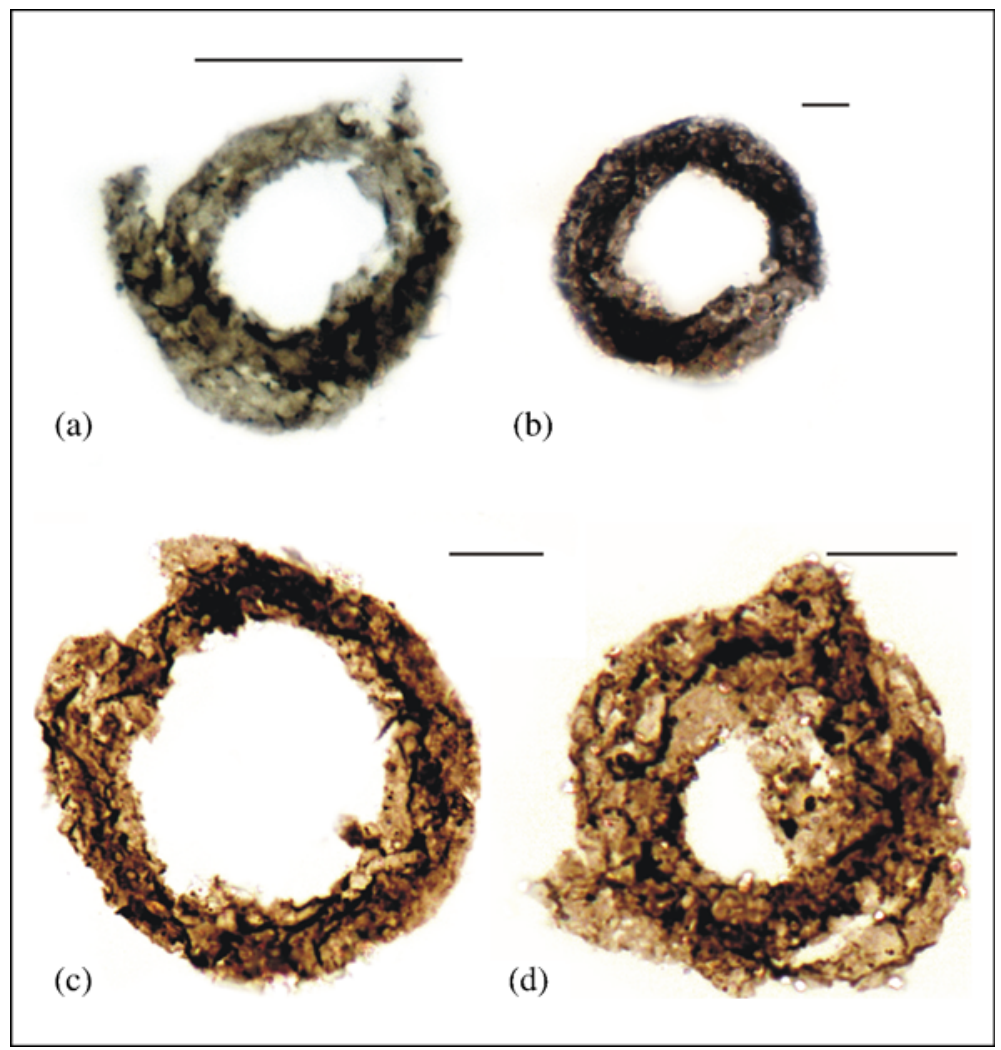

Figure 5. (a-d) Obruchevella valdaica (a) (BSIP-14401; 62/1), (b) (BSIP-14403; F41/2), (c) (BSIP-14402; K47/1), (d) (BSIP-14406; J66/3). Scale bars $=20 \mu \mathrm{m}$ for $\mathbf{b}, \mathbf{c}, \mathbf{e}, \mathbf{f} ; 10 \mu \mathrm{m}$ for $\mathbf{a}$ and $\mathbf{d}$. 
taper towards ends. In these spiral tube walls usually tightly joined to one another or can be loose. Some of the spirals may twist in other direction than main spiral direction, a feature which may be a result of post-mortem uncoiling. Total 13 specimens recorded. Spiral outer diameter is $18-44 \mu \mathrm{m}$, spiral length is up to $141 \mu \mathrm{m}$.

Remarks: Tubes of Obruchevella can be either sheaths or trichomes transformed into empty structures as a result of diagenetic alteration. Rarely septa could survive post-mortem degradation and rarely observed in case of some Obruchevella specimens.

Age and distribution: Ediacaran (Vendian): Tinna Formation, Patom Uplift, Siberia; Nagod Limestone Formation, India; Lower Cambrian: Sinna Formation, Patom Uplift, Siberia; Chulaktau Formation, South Kazakhstan; Yuhucun Formation, China; Burgess Shales, Canada.

Obruchevella parva Reitlinger, 1959, emend. Golovenok and Belova, 1989, emend. Burzin, 1995 Figure 3(a-j)

Obruchevella parva Reitlinger, 1959, p. 21, pl. VI, figures 1, 2; Kolosov, 1977, pp. 73-74, pl. VI, figure 1; 1982, pl. XVI, figures 1a, 1б; Cloud et al, 1979, pp. 87-89, figures 5J-5K; Yakschin and Luchinina, 1981, p. 30, pl. X, figures 1-3; Pyatiletov et al, 1981, figure 1.11; Golovenok and Belova, 1983, p. 1464, figures 1в-1д; Song, 1984, p. 183, figures 3.13.3, 3.8, 3.9; Sergeev, 1989, pl. 2, figures 1-3, 5, 6, 8; Sergeev and Ogurtsova, 1989, pl. I, figures 1-3, 59, 12; Golovenok and Belova, 1989, p. 193, figures 1б-1в; Sergeev, 1992a, p. 89, pl. XXIV, figures 5, 6, 11, pl. XXV, figures 1a, 1б, 2, 3, 5, 6a, 6б; Burzin, 1995, pp. 10-11, 13, pl. I, figures 1-3, 4A, pl. III, figure 1; Prasad et al 2005, pl. 10, figures 4, 12, pl. 11, figure 9; Prasad, 2007, pl. 1, figures 3, 6, 15 (for complete synonymy, see Burzin 1995 and Golovenok and Belova 1989).

Stratum typicum: Ediacaran (Vendian), Tinna Formation, Patom Uplift, Russia.

Description: Empty tubes, sometimes with rare septa coiled into regular cylindrical spiral do not taper towards ends. 10 specimens recorded. The tubes diameter ranges from 7 to $8 \mu \mathrm{m}$, spiral outer diameter is $18-60 \mu \mathrm{m}$, spiral length is up to $157 \mu \mathrm{m}$.

Remarks: Numerous emendations of Obruchevella species, especially of $O$. parva and O. delicata, in our opinion, only complicated the situation of the fossil cyanobacterium genus. Therefore, we followed the original description by Reitlinger (1948, 1959) with measure corrections done by Golovenok and Belova (1989) and our studies are based on the type material deposited in GINPC Moscow, Russia.

Age and distribution: Widely distributed in Ediacaran (Vendian) and Lower Cambrian silicified and organic-walled assemblages.

Obruchevella minor Zhang, 1984

Figure 4(a,b)

Stratum typicum: Late Sinian, Toushantou Formation, Western Hubei, China.

Description: Tubular filaments, spirally coiled and helically twisted. Helix straight to slightly curved along its length. Coiling loose, adjacent coils not touching, filaments non-septate. The diameter ranges from internal diameter 4 to $9 \mu \mathrm{m}$, spiral outer diameter is 10 to $19.5 \mu \mathrm{m}$, spiral length is up to $66 \mu \mathrm{m}$. Two specimens recorded (figure $4 \mathrm{a}$ and b). For figure 4(a), outer diameter of coil is $20 \mu \mathrm{m}$, cross sectional diameter of tube is $4 \mu \mathrm{m}$, length of the specimen is $68 \mu \mathrm{m}$. For figure 4(b), outer diameter of coil is $35 \mu \mathrm{m}$, cross sectional diameter of tube is $8 \mu \mathrm{m}$, length of the specimen is $98 \mu \mathrm{m}$.

Remarks: Zhang (1984) distinguished O. minor form the $O$. parva and $O$. delilcata on the basis of its smaller size. Moreover, the spirals are loosely coiled and adjacent coils are not touching in the case of $O$. minor. In Kurnool specimens, one specimen (figure 4a) lie exactly in the size range described by Zhang (1984). Second specimen is slightly large but due to its loosely coiled habit we placed this specimen also in $O$. minor.

Age and distribution: Late Sinian, Toushantou Formation, Western Hubei, China.

Obruchevella valdaica (Schepeleva ex msc.), Aseeva, 1974

Figure $5(\mathrm{a}-\mathrm{d})$

Volyniella valdaica: Asseva, 1974, p. 96 (part), pl. 1 , figure 1 , nonfigures 2,$3 ; 1976$, pl. XVIII, figure 1 , nonfigures $3-5 ; 1983$, pl. VI, figure 12 , nonfigure 11; Aseeva in Velikanov et al 1983, pl. XVII, figures 10, 11, non pl. XII, figure 4; Aseeva in Volkova, 1985, pl. LVI, figure 4, nonfigure 5; Hermann, 1985, p. 148, pl. LXXIV, figures 3, 6, 7; Burzin, 1995, pp. 19-23, pl. II, figures $1-5$, pl. III, figure 2.

Non Volyniella valdaica Aseeva: Ragosina, 1984, pl. I, figure 8; Ragosina and Sivertseva, 1985, pl. LVIII, figures 22-23; Pyatiletov, 1986, pl. V, figure 5. 
Obruchevella valdaica: Yankauska et al, 1989, p. 115, pl. L, figures 1, 2; Hofmann and Jackson, 1994, figures 11.18-11.22; Prasad and Asher, 2001, pl. 9, figure 9; Prasad et al, 2005, p. 54, pl. 10.5, 6; Prasad, 2007, pl. f, figures 5, 17; Shukla et al, 2006, p. 64, pl. I, figure 19.

Leiotrichoides sp.: Ragosina and Sivertseva, 1985, pl. LX, figure 9.

Spiromorpha sp.: Timofeev, 1973, pl. II, figure 10, pl. XIV, figures 7-9; non pl. XII, figure 2.

Stratum typicum: Yaryshev Formation, Podolia, Ukraine.

Diagnosis: Tubular filaments, spirally coiled and helically twisted in one or two whorls tightly compressed arrangements, coils are concentric form irregular circular structures. Trichome non-septate. In all the specimens in our collection the central part of the coiled portion is absent. The outer diameter of helix ranges from 48 to $87 \mu \mathrm{m}$, the mean helix diameter is $61.9 \mu \mathrm{m}$ and width of the filament ranges from $8-16 \mu \mathrm{m}$; mean filament width is $11.7 \mu \mathrm{m}$. Four specimens are recorded.

Remarks: The spiral forms recovered from shales were described independently as genus Volyniella (Aseeva 1974) and subsequently merged with genus Obruchevella (Yankauskas 1989; Sergeev et al 2011). However, Burzin (1995) has argued against this synonymy and suggested to keep Volyniella as an independent genus. But considering all variations within Obruchevella species, including postmortem alterations, we do not agree to Burzin and follow revision proposed by Yankauskas (1989) and Sergeev et al (2012, in press).

Age and distribution: Ediacaran, Yaryshev Formation, Podolia, Ukraine; Vendian, MogilevPodolsk Group of Volyno-Podolya, Moldavia, Redinko horizon of the north-west of the Archangelsk region; late Mesoproterozoic/earliest Neoproterozoic Thule Supergroup, Northwest Greenland; late Mesoproterozoic/earliest Neoproterozoic Baylot Supergroup, Canada. Terminal Neoproterozoic-Lower Cambrian Buxa dolomite lesser Himalaya, India; Bhander Group, Vindhyan Supergroup, India.

\section{Discussion}

Based on morphological and ecological characteristics helically coiled microfossils are divided in four broad categories.

- Obruchevella: It is a filamentous form constituted of isodiametric tubular sheath with open ends that coiled to form a cylindrical helix. Originally tightly coiled mineralized forms were assigned to this genus including sheathed and/or unsheathed forms. Subsequently, loosely coiled (Zhang 1984) sheathed and/or unsegmented forms (Song 1984) and non-mineralized specimens (e.g., Pyatiletov et al 1981) were also included in this group. Preserved cellular remains are also recorded (Song 1984; Knoll and Ohata 1988). Morphologically these forms are very similar to extant cyanobacterial group Lyngbya-Phormidium-Plectonema (LPP), however, generally it has been compared with modern Spirulina. Burzin (1995) proposed certain forms such as Volyniella which were tubular filamentous, without any cellular structure and terminally closed. Burzin (1995) considered it as a trichomatous form while in having septa whose cellular structure cross walls were selectively destroyed on burial leaving outer sheath. Similar degradational changes have been noted in most of the modern cyanobacteria. Subsequently, Volyniella has been merged with Obruchevella (Sergeev et al 2012, in press).

- Boruokia: It is a trichomatous form where no sheath has been observed and naked cells constituted helically coiled morphology. Cells are disc shaped or cylindrical and are not separated by deep constrictions. Modern Oscillatoria and Spirulina have similar morphological features.

- Grypania: It is a solitary helically coiled megascopic carbonaceous fossil which has taeniate thallus with rounded termination. No internal cellular structure has been observed. These are recorded as compression or impression forms and in some cases spirals are uncoiled. Their characteristics are discussed in detail (Walter et al 1990; Kumar 1995; Sharma and Shukla 2009a, 2009b). Morphologically these are similar to Arthrospira and Spirulina.

- Spirillopsis: Burzin (1995) established Spirillopsis as a new group of helically coiled microfossils. It is mineralized coiled form with thin tubular sheath containing pyrite grains. These grains are arranged in chain or in clusters completely filling the entire sheath. Sometimes, during preservation, spirals are uncoiled and flattened. It is similar in morphological and ecological perspective with modern benthic filamentous sulfur bacteria belonging to Beggiaotoaceae.

Obruchevella and its different species are mostly recorded from the sediments that were deposited close to Precambrian-Cambrian boundary successions. The species of Obruchevella are distinguished from other microfossils due to their distinctive coiled shape.

The Kurnool helically coiled microfossils have been taxonomically described. Their ecology, 
preservation, affinity and age connotation is being discussed in the following sections.

Ecology: Obruchevella is known from cherts, shale, limestone, dolomite and phosphorite and its excellent undistorted preservation as an organic walled microfossil suggests autochthonous burial (Burzin 1995). It has been recorded from the open shelf tidal flat environment ranging from supratidal, intertidal and to subtidal. In some of the specimens, occurrences of pyrite crystals have been demonstrated by Sergeev (1992b) in the sheath of some of the Obruchevella. This could be seen in the light that some modern cyanobacteria which are occasionally photosynthesized anaerobically have sulphur grains in their cells (Stanier et al 1981). Many strains of cyanobacteria are capable of doing anoxygenic bacterial-type photosynthesis and as a result sulphide is oxidized to elemental sulphur which was observed as refractile granules either free in the medium or adhering to the cyanobacterial filaments (Padan and Cohen 1982). Calcareous forms found in Obruchevella suggest benthic mode of life, like some modern cyanobacteria (Burzin 1995).

Preservation: The genus has been recorded from varied lithologies (chert, shale, limestone, dolomite and phosphorite). Only the tubular sheath with no traces of trichomes inside may be preserved as an organic walled form. Silicified microfossils, calcareous algae, and phosphatized remains are known in mineralized forms. In the Kurnool sediments, Obruchevella are preserved as carbonaceous remains in the Owk Shale and similar type of preservation has been reported from several places where they have been recorded from shales. Obruchevella species recorded from Yunan Province, China (Song 1984), have cross partitioning and preserved with or without sheaths. Song (1984) opined that the hollow sheaths of Obruchevella are found in two ways either the cross-partioning of trichome lost or in the filament the entire trichome degraded. Degradation might play a role to change the shape of the helix. Change in the distance between the coil, compactness of the helix and bending of the axis of helix are the resultant of post-mortem changes (Song 1984). One of the exceptional preservation of O.cf. gigantea was reported by Golovenok et al (1990) from the Parsha Formation of Yakutia as compressions on shales surfaces like Chuaria and some other carbonaceous remains are found in Meso-Neoproterozoic successions.

Affinity: Spirals of Obruchevella originally were described as foraminifera from the Vendian
(Ediacaran) Tinna and Lower Cambrian Sinna Formations of Siberia (Reitlinger 1948, 1959). Later, these fossils were reinterpreted as remains of oscillatoriacean cyanobacteria similar to modern cyanobacterium genus Spirulina (Luchinina 1975; Yakschin and Luchinina 1981; Yankauskas 1989; see Peel 1988).

It has been suggested (Cloud et al 1979) that the size of the Obruchevella varies with the age of the successions in which they are found. The Obruchevella larger than O. parva seems to be confined to the relatively younger horizons, as in the Cambrian and Ordovician rocks of former Soviet Union and North America. He concluded that the larger species of Obruchevella are of the Cambrian and younger age and O. parva is limited to the Ediacaran age. Mankiewicz (1992), in a comprehensive work, showed that the size of Obruchevella species has nothing to do with the age of the strata, and the species of one stratigraphic unit spanned the entire size range. Peel (1988) described the phosphatised helically coiled microfossils Spirellus, Obruchevella, and a new genus Jiangispirellus from the Lower Cambrian of north Greenland. All are helical forms and former two are larger than most Obruchevella species but occupy the same ecological niche. Therefore, the distribution and size parameters of the Obruchevella are independent of ecological niche and age however, most of them are confined to the Ediacaran and younger sedimentary succession.

Dongre et al (2008) proposes Mesoproterozoic age for the basin which contradicts of what is inferred from the available palaeobiological data. In the present situation, the occurrence of Obruchevella is important to ascertain the age of the basin as it is considered as typical Vendian marker genus. Previously, some workers attempted to ascertain the age of the basin on the basis of assemblage recovered from the basin and correlated the Owk Shale with the Bhander Group of Vindyan Supergroup and the Halkal Formation of Bhima basin (Salujha et al 1972; Sharma and Shukla 1999). Salujha et al (1972) reported that varied microplankton assemblage consisted of the genera that are long ranging and biostratigraphically nonpotential. Varied types of carbonaceous remains were reported by Sharma and Shukla (1999). Occurrence of Tawuia in their assemblage indicates the Neoproterozoic age of the Owk Shale. In the present study, four distinct species of Obruchevella are recorded. Among them $O$. valdaica is the largest in terms of size range. All four species have known occurrences from the Late Neoproterozoic to Early Cambrian. Thus, the age did not have any effect on the size of Obruchevella species. While analyzing the Archaean and Proterozoic biota, Knoll (1996) stated that "Although older Neoproterozoic specimens of Obruchevella 
are known, Vendian-Lower Cambrian came of this genus is a real phenomenon without adequate palaeobiological explanation".

\section{Conclusion}

- Present work records distinct species of helically coiled microfossil Obruchevella, viz., O. delicata, O. parva, O. minor and O. valdaica that made their appearance in Ediacaran as well as in Lower Cambrian strata.

- Previous report of occurrence of Tawuia in the Owk Shale suggests the Neoproterozoic age of the Owk Shale.

- Occurrence of Obruchevella in the Owk Shale together with worm burrows in the underlying Narji Limestone and Ediacaran forms in overlying Panium Quartzite collectively indicate Ediacaran age close to the Cambrian for the Owk Shale as well as for the Kurnool Group.

\section{Acknowledgements}

The authors thank Dr N C Mehrotra, Director, Birbal Sahni Institute of Palaeobotany, Lucknow, for providing infrastructure facilities, encouragement and permission (BSIP/RPCC/73-2011) to publish this paper. The help rendered by Mr Keshav Ram in preparation of slides is also acknowledged.

\section{References}

Ahluwalia A D 2002 Microbiota from lower Tal PhosphoriteChert Mussoorie Syncline: Its age and palaeoecological implications; Abstracts Geol. Soc. Australia 68 183-184.

Arya B C and Rao C N 1979 Bioturbation structures from the middle Proterozoic Narji Formation, Kurnool Group, Andhra Pradesh, India; Sedim. Geol. 22 127-134.

Aseeva E A 1974 On spiral and ring-like structures from the Upper Precambrian of Podolia; Paleontology Sbornik 2(11) 95-98.

Burzin M B 1995 Late Vendian Helicoid Filamentous Microfossils; Palaeontol. J. 29(1A) 1-34.

Cloud P E, Awramik S M, Morrison K and Hadley G 1979 Earliest Phanerozoic or Latest Proterozoic fossils from the Arabian Shield; Precamb. Res. 10 73-93.

Crawford A R and Compston W 1973 The age of the Cuddapah and Kurnool systems, southern India; J. Geol. Soc. Australia 19 453-464.

Dongre A, Chalapathi Rao N V and Kamde G 2008 Limestone xenolith in Siddanpalli Kimberlite, Gadwal granitegreenstone terrain, Eastern Dharwar Craton, Southern India: Remnant of Proterozoic Platformal cover sequence of Bhima/Kurnool age? J. Geol. 116 184-191.

Golovenok V K and Belova M Y 1983 Obruchevella from the Riphean of the Patom Highland and the Vendian of southern Kazakhstan; Doklady Akademii Nauk SSSR 272 1462-1465 (in Russian).

Golovenok V K and Belova M Yu 1989 Microfossils of Obruchevella parva Reitlinger from Vendian deposits of
Lena River basin; Doklady AN USSR 306(1) 190-193 (in Russian).

Golovenok V K, Belova M Yu and Avdeeva V I 1990 Unusual obruchevellas from the Vendian deposits of the Siberian Platform; Doklady AN USSR 315(1) 193-196 (in Russian).

Hermann T N 1985 Vendian filamentous algae; In: Vendian System (ed.) Sokolov B S (Nauka, Moscow) 1 146-151.

Hofmann H J and Jackson G D 1994 Shale-facies microfossils from the Proterozoic Bylot Supergroup, Baffin Island, Canada; Palaeontol. Soc. Memoir 37 1-39.

King W 1872 The Kudapah and Karnul Formations in the Madras Presidency; Geol. Surv. India Memoir 8346.

Knoll A 1996 Archean and Proterozoic palaeontology; In: Palynology: Principles and application (eds) Jansonius $\mathrm{J}$ and McGregor D C, American Association of Stratigraphic Palynologists Foundation 1 51-80.

Knoll A and Ohta Y 1988 Microfossils in metasediments from Prins Karls Forland, western Svalbard; Polar Res. 6 59-67.

Kolosov P N 1977 Ancient oil and gas-bearing deposits from the south-east of Siberian Platform; Nauka, Novosibirsk, 90 p.

Kolosov P N 1984 Upper Precambrian microorganisms from the east of Siberian Platform; Yakutskii Filial Sibirskogo Otdeleniya AN SSSR, Yakutsk, 84p.

Kumar S 1995 Megafossils from the Mesoproterozoic Rohtas Formation (the Vindhyan Supergroup), Katni area, Central India; Precamb. Res. 72 171-184.

Kumar S and Rai V 1992 Organic-walled microfossils from the bedded black chert of the Krol Formation (Vendian), Solan area, Himachal Pradesh, India; J. Geol. Soc. India 39(3) 229-234.

Lakshminarayan G, Bhattacharjee S and Kumar A 1999 Palaeocurrents and depositional setting in the Banganapalle Formation, Kurnool sub-basin, Cuddapah Basin, Andhra Pradesh; J. Geol. Soc. India 53 255-259.

Luchinina V A 1975 Paleoalgological characteristics of the Early Cambrian of the southeastern Siberian platform; Nauka, Novosibirsk, 100p (in Russian).

Mankiewicz C 1992 Obruchevella and other microfossils in the Burgess shale: Preservation and affinity; J. Paleontol. 66(5) 717-729.

Mishra D C 2011 Long Hiatus in Proterozoic sedimentation in India: Vindhyan, Cuddapah and Pakhal Basins - A plate tectonic model; J. Geol. Soc. India 77 17-25.

Nagaraja Rao B K, Rajurkar S T, Ramlingaswamy G and Ravindrababu B 1987 Structure and evolution of the Cuddaph basin; In: Purana basins of Peninsular India (Middle to late Proterozoic); Geol. Soc. India Memoir 6 $32-36$.

Nagovitsin K E 2000 Silicified microbiotas of the Upper Riphean of the Yenisei Ridge: News in paleontology and stratigraphy; Geol. Geof. 41(Suppl. 2/3) 7-31.

Padan E and Cohen Y 1982 Anoxygenic photosynthesis; In: The biology of cyanobacteria Botanical Monographs (eds) Carr N G and Whitton B A, Blackwell Scientific Publications, 19 688p.

Pashkevichene L T 1980 Acritarchs from transitional Vendian-Cambrian strata of the East European Platform western part; Moscow, Nauka 76p (in Russian).

Peel J S 1988 Spirellus and related helically coiled microfossils (cyanobacteria) from the lower Cambrian of north Greenland; Rapp. Gronlands Geol. Unders. 137 $5-32$.

Prasad B 2007 Obruchevella and other terminal Proterozoic (Vendian) organic walled microfossils from the Bhander Group (Vindhyan Supergroup), Madhya Pradesh; J. Palaeont. Soc. India 69 295-310. 
Prasad B and Asher R 2001 Biostratigraphy and lithostratigraphic classification of Proterozoic and Lower Paleozoic sediments (Pre-Unconformity Sequence) of Ganga Basin, India; Paleontographica Indica 5 151p.

Prasad B, Uniyal S N and Asher R 2005 Organic-walled microfossils from the Proterozoic Vindhyan Supergroup of Son Valley, Madhya Pradesh, India; Palaeobotanist 54 $13-60$.

Pyatiletov V G 1986 Precambrian microphytofossils from the Kattanga saddle and adjacent territories (western part of the Siberian platform); In: Pozdnii Dokembrii $i$ Rannii Paleozoi Sibiri. Stratigrafiya $i$ Paleontologiy (eds) Khomentovskii V V and Shenfil' V Y (Novosibirsk: Nauka), pp. 129-164 (in Russian).

Pyatiletov V G, Luchinina V A, Schenfil' V Yu and Yakschin M S 1981 New data on ancient algae of Siberia; Doklady AN USSR 261(4) 982-983 (in Russian).

Ragosina A L 1984 Microfossils of the Belomorian Vendian biota and their stratigraphic significance; In: Stratigraphy and palaeontology of ancient phanerozoic (Moscow: Nauka), pp. 25-30 (in Russian).

Ragosina A L and Sivertseva I A 1985 Microfossils from Valday Group from northwestern Arkhangelsk district; In: Vendian System (ed.) Sokolov B S (Moscow: Nauka) 1 139-145.

Rai V and Singh V K 2004 Discovery of Obruchevella Reitlinger, 1948 from the late Palaeoproterozoic lower Vindhyan succession and its significance; J. Palaeont. Soc. India 49 189-196.

Rajurkar S T 1963 Discoidal impressions akin to Fermoria from the Owk Shales of Kurnool district, Andhra Pradesh; Indian Minerals 17(3) 306-307.

Reitlinger E A 1948 Cambrian foraminifera of Yakutsk; Byulleten Moskovskogo Obshchestva Ispytateleja Priody, Otdel Geologicheskii 23(2) 77-81 (in Russian).

Reitlinger E A 1959 Atlas of microscopic organic remains and problematica of ancient deposits of Siberia; (Moscow: Academiya Nauk SSSR), 62p (in Russian).

Raman P K and Murty V N 1997 Geology of Andhra Pradesh; Geol. Soc. India, Bangalore, p. 235.

Salujha S K, Rehman K and Arora C M 1972 Early Palaeozoic microplankton from the Kurnools, Andhra Pradesh; J. Palynol. 8 123-131.

Sergeev V N 1989 Microfossils from transitional Precambrian-Phanerozoic strata of Central Asia; Himalayan Geol. 13 269-278.

Sergeev V N 1992a Silicified microfossils from the Precambrian and Cambrian deposits of the southern Ural Mountains and Middle Asia (Moscow: Nauka), 134p (in Russian).

Sergeev V N 1992b Microfossils in cherts from Precambrian and Cambrian of southern Ural Mountains and Middle Asia; Nauka, Moscow; Tra. Geol. In-ta AN SSSR 474 139 p (in Russian).

Sergeev V N and Ogurtsova R N 1989 Microbiota from the Lower Cambrian phosphatic deposits of the Maly Karatau (South Kazakhstan); Izvestiya Akademiya Nauk SSSR, Seriya Geologicheskaya 3 58-66 (in Russian).

Sergeev V N, Sharma M and Shukla Y 2012 Proterozoic Fossil Cyanobacteria; Monograph on Precambrian microfossils (in press).

Sharma M 2008 Neoproterozoic biotic signatures in the peninsular Indian Basins - An Overview; Geol. Soc. India Memoir 74 119-131.

Sharma M and Shukla M 1999 Carbonaceous megaremains from the Neoproterozoic Owk Shales Formation of the
Kurnool Group, Andhra Pradesh, India; Curr. Sci. 76(9) 1247-1251.

Sharma M and Shukla Y 2009a Mesoproterozoic coiled megascopic fossil Grypania spiralis from the Rohtas Formation, Semri Group, Bihar, India; Curr. Sci. 96 16361640 .

Sharma M and Shukla Y 2009b Taxonomy and affinity of Early Mesoproterozoic megascopic helically coiled and related fossils from the Rohtas Formation, the Vindhyan Supergroup, India; Precamb. Res. 173 $105-122$

Shukla M, Tewari V C, Babu R and Sharma A 2006 Microfossils from the Neoproterozoic Buxa Dolomite, West Siang District, Arunachal Lesser Himalaya, India and their significance; J. Palaeont. Soc. India 51(1) 57-73.

Song X 1984 Obruchevella from the early Cambrian Meishucun stage of the Meishucun section, Jinning, Yunnan, China; Geol. Mag. 121(3) 179-183.

Stanier R Y, Pfenning N and Truper H G 1981 Introduction to the phototrophic prokaryotes; In: The Prokaryotes. A Handbook on Habitats, Isolation and Identification of Bacteria (ed.) Starr M P (Berlin, Heidelberg, NY: Springer-Verlag), 1 197-211.

Tewari V C 2007 The rise and decline of the Ediacaran biota: Palaeobiological and stable isotopic evidence from the NW and NE Lesser Himalaya, India; In: The rise and fall of the Ediacaran Biota (eds) Vickers-Rich $\mathrm{P}$ and Komarower P, Geol. Soc. Spec. Publ. 286 77-102.

Timofeev B V 1973 Microphytofossils from the Precambrian of Ukraine; (Leningrad: Nauka), 100p (in Russian).

Tiwari M and Knoll A H 1994 Large acanthomorphic acritarchs from the Infrakrol Formation of the Lesser Himalayas and their stratigraphic significance; Himalayan Geol. 5 193-201.

Tiwari M and Pant I 2009 Microfossils from the Neoproterozoic Gangolihat Formation, Kumaun Lesser Himalaya: Their stratigraphic and evolutionary significance; J. Asia Earth Sci. 35 137-149.

Valdiya K S 2010 The making of India: Geodynamic evolution; Macmillan Publishers India Ltd., 816p.

Velikanov V A, Asseva E A and Fedonkin M A 1983 Vendian of Ukraine; Naukova Dumka, Kiev, 164p (in Russian).

Vijayam B E 1967 Worm burrows in Narji Limestones, near Govindinne, Kurnool Dist., A.P.; Curr. Sci. 37(5) 142.

Volkova N A 1985 Acritarchs and other plant microfossils of the East-European Platform: 130-139; In: The Vendian System 1, Palaeontology (eds) Sokolov B S and Ivanovskii A B (Moscow: Nauka), English translation published in 1990, The Vendian System (Berlin: Springer-Verlag), 1 $179-188$.

Walter M R, Du R and Horodyski R J 1990 Coiled carbonaceous megafossils from the Middle Proterozoic of Jixian (Tianjin) and Montana; Am. J. Sci. 290(A) 133148.

Yakschin M S and Luchinina V A 1981 New data on fossilized algae of family Oscillatoriaceae (Kirchn.) Elenkin; In: Precambrian-Cambrian boundary deposits of the Siberian platform (Novosibirsk: Nauka), pp. 28-34 (in Russian).

Yankauskas T V (ed.) 1989 Precambrian microfossils of the USSR; (Leningrad: Nauka), 188p (in Russian).

Zhang Z 1984 On the occurrence of Obruchevella from the Toushantou Formation (Late Sinian) of western Hubei and its significance; Acta Palaeontol. Sin. 23(4) 447-451 (with English summary). 